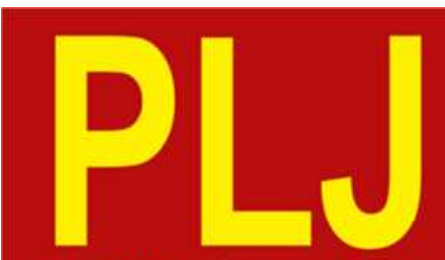

ISSN: $2540-7716$ | e-1SSN: $2540-9166$

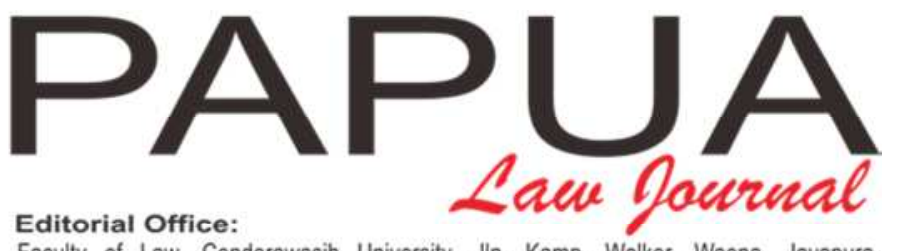

Faculty of Law, Cenderawasih University. Jln. Kamp. Wolker, Waena, Jayapura, 99358, Papua, Indonesia. Tel./Fax:+62-967-585470E-mail: papualawjoumal@unicen.ac.id papualawjournal@gmail.com Website: http://ejournal.fhuncen.ac.id/index.php/plj

\title{
Kedudukan Laboratorium Klinik Dan Bantuan Hukum Dalam Mengemban Tri Dharma Perguruan Tinggi (Studi Kasus Pada Fakultas Hukum Uncen)
}

\author{
Ispurwandoko Susilo \\ Fakultas Hukum Universitas Cenderawasih \\ Jl. Kamp. Wolker, Waena, Jayapura, 99358, Papua, Indonesia \\ Tel./Fax.: +62-967-585470 E-mail:ispurwandokosusilo@gmail.com
}

\begin{abstract}
Abstrak: Laboratorium Klinik dan Bantuan Hukum (LKBH) mempunyai peran yang penting dalam mengemban Tri Dharma Perguruan Tinggi, karena ketiga dharma tersebut, yaitu dharma pendidikan, dharma penelitian dan dharma pengabdian kepada masyarakat dilaksanakan oleh LKBH yang ada pada Fakultas Hukum. Objek tulisan ini terkait dengan kedudukan laboratorium klinik dan bantuan hukum dalam mengemban Tri Dharma Perguruan Tinggi, dengan menggunakan metode yuridis normative. Hasil penelitian menunjukkan bahwa sejak Undang-Undang Nomor 18 Tahun 2003 tentang Advokat diundangkan, kedudukan LKBH perguruan tinggi nyaris hilang, karena dalam Pasal 31 ada larangan dan sanksi pemidanaan bagi orang yang menjalankan bantuan hukum atau jasa hukum dan bertindak seolah-olah advokat dengan ancaman pidana penjara maksimal 5 (lima) tahun dan denda lima puluh juta rupiah, namun sejak dilakukan judicial review ke Mahkamah Konstitusi atas UU Nomor 18 Tahun 2003 pada Pasal 31, kedudukan LKBH perguruan tinggi semakin jelas yaitu diperkenankan memberikan bantuan hukum. Kedudukan LKBH perguruan tinggi semakin rinci diatur di dalam UU Nomor 16 Tahun 2011 tentang Bantuan Hukum. Dalam undang-undang tersebut, LKBH perguruan tinggi dikelompokkan sebagai organisasi atau lembaga pemberi bantuan hukum.
\end{abstract}

Kata kunci: Pendidikan, Penelitian, Bantuan Hukum, Pengabdian Kepada Masyarakat

\section{PENDAHULUAN}

Dalam negara hukum (rechstaat) negara mengakui dan melindungi hak asasi manusia setiap individu.

Pengakuan negara terhadap hak individu ini tersirat di dalam persamaan kedudukan dihadapan hukum bagi semua orang. Di dalam negara hukum semua orang harus diperlakukan sama dihadapan hukum (equality before the 
law). Persamaan dihadapan hukum sekelompok elit gereja terhadap harus diimbangi juga dengan pengikut-pengikutnya. Konsep bantuan persamaan perlakuan (equal treatment). hukum tersebut membangun suatu pola Kalau seorang yang mampu hubungan klien dan patron, dimana mempunyai masalah hukum ia dapat pemberian bantuan hukum lebih menunjuk seorang atau lebih advokat banyak tergantung kepada kepentingan untuk membela kepentingannya. patron yaitu patron ingin melindungi

Sebaliknya seorang yang tergolong tidak mampu juga dapat meminta pembelaan dari seorang atau lebih advokat dan atau pembela umum sebagai pekerja di lembaga bantuan hukum (legal aid institute) untuk membela kepentingannya dalam suatu perkara hukum. Perolehan perlindungan dan perlakuan sama dalam hukum yang tidak boleh diabaikan haknya untuk memperoleh pembelaan dari seorang advokat atau pembela umum dengan tidak memperhatikan latar belakangnya, seperti latar belakang agama, keturunan, ras, etnis, keyakinan politik, strata ekonomi-sosio, warna kulit dan gender. $^{1}$

James Gordley dan Mauro Cappeleti dalam tulisan Uli Parulian Sihombing mencatat bahwa bantuan hukum lahir dari sikap kedermawanan

1
unswagati.blogspot.com//,bbkh-
diakses 9 November 2013
kliennya. Sehingga bantuan hukum ditafsirkan sebagai bantuan (charity) yang dalam perkembangannya tidak lagi menjadi charity tapi lebih dari itu yaitu hak yang dikenal dengan dua istilah legal aid dan legal assistance.Perubahan ke Charity bisa dilihat kalau di Indonesia dalam Undang-Undang Nomor 8 Tahun 1981 tentang KUHAP (UU No. 8 Tahun 1981) dan Undang-Undang Nomor 4 Tahun 2004 tentang Kekuasaan Kehakiman (UU No. 4 Tahun 2004).

Legal Aid adalah istilah bantuan hukum bagi orang yang miskin (Kaum Dhuafa) yang tidak mampu membayar lawyer yang melahirkan konsep Lembaga Bantuan Hukum (LBH), dan semacamnya yang disebut pekerja pemberi bantuan hukum (public defender), sedangkan Legal Assistance untuk orang yang mampu membayar lawyer. Kedua istilah tersebut lahir dari negara-negara maju dan di Indonesia 
sendiri diperkenalkan jaman Hindia oleh organisasi profesi, (c) Organisasi Belanda dalam Pasal 250 Het Herziene yang berkaitan dengan kekuatan sosial, Inlands Reglement (HIR) sebagai (d) Organisasi yang dibentuk oleh hukum formil dalam perkara pidana kelompok kepentingan, dan (e) dan perdata. Di pasal itu disebutkan Organisasi yang didirikan oleh Advokat memberikan bantuan hukum kelompok-kelompok sosial. apabila ada permintaan dari orang yang dituduh serta diancam dengan hukuman mati.

Setelah Indonesia merdeka, HIR tetap berlaku berdasarkan ketentuan peralihan dalam UUD 1945 pra amandemen dan kemudian menjadi tidak berlaku dalam wilayah hukum pidana seiring dengan diberlakukannya Undang-Undang No. 8 Tahun 1981 tentang Kitab Undang-Undang Hukum Acara Pidana (KUHAP), dan UU No. 4 Tahun 2004 Tentang Kekuasaan Kehakiman. ${ }^{2}$

Penyelenggaraan bantuan hukum secara garis besarnya terbagi dalam beberapa wadah. Menurut Mulyana W. Kusumah $^{3}$ wadah bantuan hukum meliputi (a) Organisasi yang bernaung di bawah Fakultas Hukum Negeri dan Swasta, (b) Organisasi yang dibentuk

\footnotetext{
${ }^{2}$ Uli Parulian Sihombing, "Perkembangan Bantuan Hukum dan Tanggungjawab negara” www. hukumonline. com.

${ }^{3}$ Mulyana W.Kusumah, (1983). Bantuan Hukum dan Pemeratan Keadilan, Jakarta: Lembaga Kriminologi UI, hal. 2
}

Organisasi yang bernaung di bawah Fakultas Syariah dan Fakultas Hukum baik negeri maupun swasta pada umumnya menggunakan nama Lembaga Konsultasi dan Bantuan Hukum $(\mathrm{LKBH})^{4}$, sekalipun pada beberapa kampus menyebutnya dengan nama LBH.

Sejak Undang-Undang Nomor 18 Tahun 2003 tentang Advokat (UU No. 18 Tahun 2003) diundangkan, posisi, peran dan kedudukan LKBH kampus semakin terpinggirkan. Pasal 31 Undang-undang Advokat menyatakan bahwa "setiap orang yang dengan sengaja menjalankan profesi advokat dan bertindak seolah olah sebagai advokat tetapi bukan advokat dikenakan pidana penjara paling lama 5 (lima) tahun dan denda paling banyak 50.000.000,00 (lima puluh juta rupiah)".

\footnotetext{
${ }^{4}$ Frans Hendra Winarta, (2000). Bantuan Hukum: Suatu Hak Asasi Manusia Bukan Belas Kasihan, Jakarta: PT Elex Media Komputindo, hal. 50
} 
Keberadaan pasal tersebut ternyata tidak memberikan spesifikasi khusus terhadap jasa advokasi yang diberikan oleh LKBH yang berada di bawah perguruan tinggi. Itu artinya jasa advokasi yang diberikan oleh mahasiswa atau oleh sarjana hukum yang belum memiliki ijin sebagai advokat sebagaimana di atur dalam undang-undang advokat dianggap melanggar ketentuan Pasal 31 tersebut. Padahal selama ini upaya advokasi yang diberikan oleh mereka yang pada umumnya berstatus sebagai mahasiswa atau seorang sarjana hukum yang belum memiliki ijin, adalah sebagai media praktik untuk menuangkan dan mengaplikasikan ilmunya dalam masyarakat terutama pada masyarakat yang tidak mampu yang memang menjadi bidang garap mereka dan yang secara khusus menjadi sasaran orientasi dari adanya bantuan hukum di Perguruan Tinggi. ${ }^{5}$

Pasal 31 dalam UU Nomor 18 tahun 2003, kemudian dilakukan yudicial review oleh sekelompok dosen dari Fakultas Hukum Universitas

\footnotetext{
${ }^{5}$ Karimatul Ummah, "Implikasi UU No.18 tahun 2003 Terhadap Keberadaan Lembaga Bantuan Hukum Milik Perguruan Tinggi" dalam Jurnal al-Mawarid. Edisi XII Tahun 2004, hal 3.
}

Muhammadiyah Malang (UMM) yang diajukan oleh Tongat selaku Kepala Laboratorium Konsultasi dan Pelayanan Hukum Fakultas Hukum UMM pada tahun 2004. Mahkmah Konstitusi (MK) akhirnya menjatuhkan putusan atas permohonan pengujian UU No. 18 Tahun 2003 yang amar putusannya mengatakan bahwa "Pasal 31 UU Nomor 18 Tahun 2003 tidak memiliki kekuatan hukum". 6

Berdasarkan uraian di atas, posisi LKBH di perguruan tinggi menjadi terbuka untuk bisa bersaing dengan kantor hukum yang dikelola oleh organisasi profesi. Oleh karena itu, rumusan masalah yang dikaji dalam tulisan ini adalah bagaimana kedudukan LKBH kampus pasca UU No. 18 Tahun 2003 dan putusan MK serta peran apa yang bisa dilakukan oleh perguruan tinggi di dalam memberikan bantuan hukum.

\section{METODE}

Penelitian ini menggunakan metode pendekatan yuridis normatif, dimana tata cara untuk menemukan dan merumuskan argumentasi hukum

\footnotetext{
${ }^{6}$ Putusan Mahkamah Konstitusi Nomor 006/PUU-II/2004
} 
melalui pemanfaatan teori dan konsep dalam ilmu hukum dan penalaran hukum sebagai instrumen analisis terhadap permasalahan hukum, yang disebabkan adanya kekosongan hukum, konflik norma maupun norma tersamar. Penggunaan penalaran hukum (legal reasoning) dengan tahapan pemecahan masalah hukum (legal problem solving, legal analysis), yang terdiri dari: pengumpulan fakta hukum, klasifikasi hakikat permasalahan hukum dan identifikasi isu hukum yang relevan, sementara itu, analisis dilakukan berdasarkan penyebab timbulnya masalah (isu hukum), yaitu: analisis berfokus pada metode penemuan hukum (rechtsvinding) untuk masalah yang disebabkan oleh adanya kekosongan hukum, analisis berfokus metode penyelesaian konflik untuk masalah yang disebabkan oleh adanya konflik norma, dan analisis berfokus pada metode interpretasi untuk masalah yang disebabkan penerapan norma tersamar.

\section{PEMBAHASAN}

\section{Sekilas tentang Bantuan Hukum di Indonesia}

Indonesia sebagai negara yang menganut paham negara hukumberdasarkan Pasal 1 ayat (3) UUD $1945,{ }^{7}$ harus menjunjung tinggi hak asasi manusia dalam segala bentuk. Bentuk perlindungan terhadap hak asasi manusia, diantaranya adalah dengan memberi jaminan dan perlindungan agar setiap orang memiliki kedudukan yang sama di hadapan hukum dengan tidak ada pengecualiannya. Adanya jaminan dan perlindungan tersebut memberikan petunjuk akan pentingnya bantuan hukum guna menjamin agar setiap orang dapat terlindungi hak-haknya dari tindakan hukum yang diskriminatif sehingga apa yang menjadi tujuan negara untuk menciptakan persamaan di hadapan hukum, dapat terlaksana karena berjalannya fungsi dari bantuan hukum tersebut. ${ }^{8}$

Bantuan hukum merupakan hal yang sangat esensial dalam menciptakan kehidupan yang adil serta melindungi hak asasi manusia dimana

\footnotetext{
${ }^{7}$ Undang-Undang Dasar Negara Republik Indonesia, Pasal 1 ayat (3) : "Negara Indonesia adalah Negara hukum"

8 Bagir Manan, (2001). Perkembangan Pemikiran dan Pengaturan Hak Asasi Manusia di Indonesia, Yayasan Hak Asasi Manusia, Semokrasi dan Supremasi Hukum, Bandung: Alumni, hal. 59.
} 
bantuan hukum yang diberikan Kekuasaan Kehakiman yang di bertujuan untuk melindungi hak asasi dalamnya antara lain mengatur secara masyarakat dalam hal masalah hukum jelas tentang hak seseorang untuk guna menghindari segala macam mendapatkan bantuan hukum ketika tindakan yang dapat membahayakan terjerat suatu masalah hukum yang atau tindakan sewenang-wenang aparat mengharuskannya berhubungan dengan penegak hukum atau aparat lembaga penegakan hukum. Lahirnya pemerintahan.

peraturan tersebut merupakan realisasi

Pelaksanaan bantuan hukum di Indonesia saat ini diatur dalam Undang-Undang Nomor 16 tahun 2011 tentang Bantuan Hukum (UU No. 16 Tahun 2011). Penerima bantuan hukum berdasarkan UU No. 16 Tahun 2011 hanyalah terbatas pada orang atau kelompok orang miskin saja. Padahal menurut Undang-Undang Dasar 1945 Pasal 27 ayat (1) dan Pasal 28 d ayat (1) serta Undang-Undang Nomor 39 tahun 1999 Pasal 5 ayat (3), penerima bantuan hukum adalah setiap warga masyarakat tanpa terkecuali, termasuk didalamnya adalah kelompok masyarakat rentan. ${ }^{9}$

Setelah Indonesia mencapai kemerdekaannya, pada tahun 1964 di undangkannya Undang-Undang Nomor 19 Tahun 1964 tentang Pokok Pokok

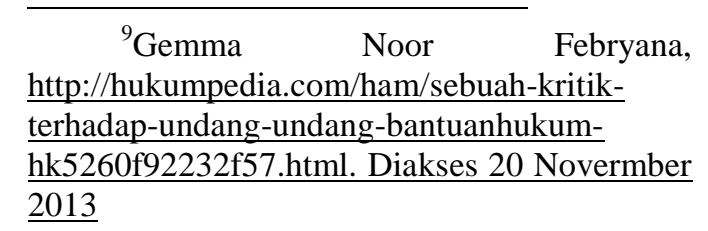
dari pelaksanaan Pasal 27 ayat (1) UUD 1945 bahwa setiap Warga Negara bersamaan kedudukannya dalam hukum dan pemerintahan dan wajib menjunjung hukum dan pemerintahan itu dengan tidak ada kecualinya.

Sejarah dan perkembangan bantuan hukum di Indonesia tak lepas dari peran serta lembaga bantuan hukum. Meskipun sudah ada UndangUndang tersendiri tentang bantuan hukum, namun pengertian dari Lembaga Bantuan Hukum sendiri belum secara khusus dirumuskan. Meskipun begitu, dalam Peraturan Pemerintah Republik Indonesia No. 83 Tahun 2008 tentang Persyaratan dan Tata Cara Pemberian Bantuan Hukum Secara Cuma-Cuma, memberikan pengertian dari lembaga ini, yang diatur dalam Pasal 1 angka 6, dimana dikatakan bahwa Lembaga Bantuan Hukum (LBH) adalah lembaga yang 
memberikan bantuan hukum kepada pencari keadilan tanpa menerima pembayaran honorarium. Adapun LBH didirikan dengan konsep awal melindungi masyarakat dari penindasan hukum yang kerap menimpa mereka. Konsep ini kemudian dituangkan dalam Anggaran Dasar LBH yang didalamnya disebutkan bahwa tujuan LBH adalah:

a. Memberi pelayanan hukum kepada rakyat miskin;

b. Mengembangkan dan meningkatkan kesadaran hukum rakyat, terutama mengenai hakhaknya sebagai subjek hukum;

c. Mengusahakan perubahan dan perbaikan hukum untuk mengisi kebutuhan baru dari masyarakat yang berkembang. ${ }^{10}$

Dalam perkembangannya Lembaga Bantuan Hukum terbagi dalam dua kelompok yaitu:

a. Lembaga Bantuan Hukum Swasta. Lembaga inilah yang telah muncul dan berkembang belakangan ini. Anggotanya pada umumnya terdiri dari kelompok yang bergerak dalam profesi hukum pengacara. Konsep dan peranannya jauh lebih luas dari sekedar memberi bantuan hukum

10 Binziad Kadafi, dkk., (2002). Advokat Indonesia Mencari Legitimasi Studi Tentang Tanggung Jawab Profesi Hukum di Indonesia, Jakarta: Pusat Studi Hukum \& Kebijakan Indonesia, hal.163. secara formal di depan sidang Pengadilan terhadap rakyat kecil yang miskin dan buta hukum. Konsep dan programnya dapat dikatakan:

1) Menitikberatkan bantuan dan nasihat hukum terhadap lapisan masyarakat kecil yang tidak mampu;

2) Memberi nasihat hukum di luar pengadilan terhadap buruh, tani, nelayan, dan pegawai negeri yang merasa haknya "diperkosa".

3) Mendampingi atau memberi bantuan hukum secara langsung di sidang pengadilan baik yang meliputi perkara perdata dan pidana.

4) Bantuan dan nasihat hukum yang mereka berikan dilakukan secara cumacuma.

b. Lembaga Bantuan Hukum yang Bernaung Pada Perguruan Tinggi.

Lembaga ini sering dikenal dengan nama Biro Bantuan Hukum. Lembaga inipun hampir sama dengan Lembaga Bantuan Hukum swasta, tetapi lembaga ini akhirnya kurang begitu populer. $^{11}$

\section{Kedudukan LKBH Kampus Pasca Judicial Review}

Pasal 31 Undang-undang Nomor 18 Tahun 2003 tentang Advokat

11 Ramses Harry Doan Sinaga, Peranan Lembaga Bantuan Hukum Dalam Memberikan Bantuan Kepada Masyarakat Di Bidang Perdata (Studi di LBH Medan dan LBH Trisila Sumatera Utara) 
akhirnya dilakukan Judicial Review

oleh Laboratorium Konsultasi dan Pelayanan Hukum (LKPH) UMM ke Mahkamah Konstitusi (MK). Dalam amar putusannya MK menyatakan bahwa, Pasal 31 Undang-undang Nomor 18 Tahun 2003 tentang Advokat bertentangan dengan UndangUndang Dasar Negara Republik Indonesia Tahun 1945, Pasal 31 Undang-undang Nomor 18 Tahun 2003 tentang Advokat tidak mempunyai kekuatan hukum mengikat dan memerintahkan pemuatan putusan ini dalam Berita Negara Republik Indonesia sebagaimana mestinya. Pencabutan Pasal 31 UU No. 18 Tahun 2003 Tentang Advokat oleh MK melahirkan babak baru dalam dunia bantuan hukum. Sebelumnya, keberadaan UU Advokat menjadi kuburan mati dan mimpi buruk bantuan hukum bagi masyarakat tidak mampu dan LKBH Perguruan Tinggi, betapa tidak, sebelum UU Advokat lahir bantuan hukum masyarakat tidak mampu (justice for all) disuplai LKBH yang konsisten pada pengabdian masyarakat sebagai wujud Tri Dharma Perguruan Tinggi.
UU Advokat menjadi kuburan mati dan mimpi buruk disebabkan dua hal. Pertama monopoli bantuan hukum yang hanya boleh dilaksanakan dan dilakukan Advokat sebagaimana diatur dalam Pasal 1, kedua pemidanaan bagi orang yang menjalankan bantuan hukum atau jasa hukum dan bertindak seolah-olah Advokat dengan ancaman pidana penjara maksimal 5 (lima) tahun dan denda Rp. 50.000.000,- (lima puluh juta rupiah) sebagaimana diatur dalam Pasal 31. UU Advokat disatu sisi telah merampas hak dan kewajiban LKBH Perguruan Tinggi dan hak masyarakat tidak mampu memperoleh bantuan hukum cuma-cuma yang telah lama ada dengan ijin dari Mahkamah Agung yang diperpanjang dalam Surat Mahkamah Agung (MA) No. MA/SEK/034/II/2003 Tentang Ijin Praktek Bantuan Hukum Bagi Lembaga Hukum Fakultas/Sekolah Tinggi Hukum.

Jika dilihat secara mendalam ada dua komponen dalam negara yang dirugikan dengan lahirnya UU Advokat. Pertama, adalah Perguruan Tinggi C.q. LKBH yang mempunyai kewajiban menjalankan fungsi pengabdian masyakat sebagaimana 
diamanahkan dalam Pasal 20 Ayat (2) UU No. 20 Tahun 2003 Tentang Sistem Pendidikan Nasional, dimana disebutkan bahwa Perguruan Tinggi berkewajiban menyelenggarakan pendidikan, penelitian dan pengabdian masyarakat yang salah satunya adalah memberikan bantuan hukum cumacuma bagi masyarakat yang tidak mampu melalui LKBH. Kedua, masyarakat (civil society) tidak mampu untuk memperoleh bantuan hukum cuma-cuma dari LKBH yang hak tersebut sesungguhnya telah diberikan UUD 1945 Pasal 28D ayat (1) bahwa "setiap orang berhak atas pengakuan, jaminan, perlindungan, dan Kepastian hukum yang adil serta perlakuan yang sama didepan hukum". 12

Undang-undang Advokat yang mulai berlaku tahun 2003 boleh dikatakan membawa angin segar bagi profesi advokat. Tetapi tidak bagi keberadaan LKBH Perguruan Tinggi. Sebab dengan diberlakukannya UU Advokat, peranan sejumlah $\mathrm{LKBH}$

\footnotetext{
${ }^{12}$ Siti Mulyani, (2006). Penerapan Putusan Mahkamah Konstitusi No.06/PUU-II/2004 Pasca Yudisial Review terhadap UU No. 18 tahun 2003 tentang Advokat (studi di Kepolisian, Kejaksaan, dan Pengadilan Negeri Kota Malang), Laporan Penelitian, FH UMM, hal. 6
}

perguruan tinggi makin dibatasi. Demikian pula LKBH perguruan tinggi negeri, dosen-dosen yang melakukan tugas ganda sebagai pengacara tidak akan lagi dapat berpraktik sebagai advokat di pengadilan. Sebab, pasal 3 ayat (1) UU advokat memberi larangan bagi seorang pegawai negeri untuk melakukan advokasi di pengadilan.

UU advokat yang hadir di tengah kancah dunia peradilan memang merupakan sandungan berat bagi dosen universitas negeri untuk beracara. Dengan adanya UU Advokat, otomatis hanya bisa memberi konsultasi. UU Advokatpun bukan saja meneror kerja LKBH Kampus Negeri, tapi keberadaan perangkat hukum baru ini juga mengkhawatirkan LKBH Kampus Swasta. Sebab tidak semua dosen yang bekerja di LKBH kampus sudah memiliki SKPT. Oleh karena itulah, Tongat, Ketua LKPH (Laboratorium Konsultasi dan Pelayanan Hukum) Universitas Muhammadiyah Malang membawa masalah pembatasan kegiatan advokat ini lewat jalur judicial review di Mahkamah Konstitusi.

Menurut Tongat, ancaman pidana yang diterapkan dalam UU Advokat dapat menjadi belenggu bagi 
universitas untuk membuat misi sosial yang dilakukan oleh LKBH Kampus. Tidak ada pengecualian dalam UU Advokat yang memberikan jalur untuk pelayanan hukum kampus. UU Advokat seolah-olah telah melakukan pembredelan terhadap peran dan fungsi LKPH dalam memberi bantuan hukum cuma-cuma. Secara perlahan UU Advokat sebagai kendala yuridis akan menghapus peran dan fungsi lembagalembaga bantuan hukum non profit yang berorientasi kepada masyarakat yang tidak mampu. Sebagai jalan keluar untuk mengatasi kepunahan LKBH pergguruan tinggi, secara perlahan-lahan, sudah selayaknya organisasi advokat membuat sebuah aturan yang mengecualikan LKBH perguruan tinggi dari ketentuan UU Advokat. Sehingga LKBH perguruan tinggi dapat lebih melebarkan sayapnya. Apalagi, kualitas pemberian bantuan hukum oleh dosen maupun mahasiswa belum tentu kalah dengan kualitas advokat. Selain itu, LKBH perguruan tinggi sudah sepatutnya dijadikan tempat magang seperti yang dimaksud dalam UU Advokat. Artinya, magang selama dua tahun di LKBH pergurruan tinggi harus dianggap sama dengan magang di sebuah kantor hukum. Setelah dua tahun magang di LKBH perguruan tinggi, mereka bisa mendapat kartu advokat untuk beracara. ${ }^{13}$ Setelah melalui perjuangan melalui yudicial review, LKBH perguruan tinggi mendapat tempat dalam melakukan kegiatan bantuan hukum. LKBH perguruan tinggi memulai babak baru dengan mimpi indahnya untuk kembali memberikan layanan atau bantuan hukum kepada masyarakat miskin secara gratis (pro deo/pro bono publico) dan menjalankan tugasnya sebagai public defender berpegang pada Putusan Mahkamah Konstitusi No. 006/PUUII/2004 yang membatalkan Pasal 31 UU Advokat yang berisi tentang pemidanaan orang yang memberikan bantuan hukum baik luar dan dalam pengadilan (litigasi dan nonlitigasi).

Kedudukan LKBH perguruan tinggi pasca UU Advokat dan Putusan MK semakin jelas, yaitu menempati posisi sebagai lembaga yang diperbolehkan memberikan bantuan hukum. Namun kejelasan itu hanya

\footnotetext{
${ }^{13}$ www.hukumonline.com. Kiprah LBH Kampus Digilas Roda Waktu, Jumat, 13 Agustus 2004
} 
implisit saja disebutkan dalam UU berbentuk organisasi atau lembaga Nomor 16 Tahun 2011 tentang Bantuan yang memungkinkan LKBH perguruan Hukum. Dalam UU Nomor 16 Tahun tinggi bisa juga dikualifikasi sebagai 2011 Pasal 1 angka1 disebutkan bahwa pemberi bantuan hukum apabila yang dimaksud dengan bantuan hukum kriteria lembaganya telah memenuhi adalah jasa hukum yang diberikan oleh Pemberi Bantuan Hukum secara cumasyarat sebagaimana diatur dalam Pasal 8 ayat (3) yaitu berbadan hukum, cuma kepada Penerima Bantuan terakreditasi berdasarkan UndangHukum. Pasal 1 angka 3 menyebutkan siapa yang dimaksud dengan pemberi bantuan hukum. Pemberi Bantuan Hukum adalah lembaga bantuan hukum atau organisasi kemasyarakatan yang memberi layanan Bantuan Hukum berdasarkan Undang-Undang ini.

Undang ini, memiliki kantor atau sekretariat yang tetap, memiliki pengurus dan memiliki program bantuan hukum.

Mencermati kriteria pemberi bantuan hukum seperti di atas, maka kedudukan LKBH perguruan tinggi

Ketentuan dalam Pasal 1 angka 1 dan angka 3 membatasi dengan jelas bahwa konsep bantuan hukum yang diberikan oleh pemberi bantuan hukum dilakukan kepada masyarakat secara dapat disejajarkan sebagai pemberi bantuan hukum. Ketentuan mengenai hal ini, dapat dikaji di dalam PP Nomor 42 Tahun 2013 tentang Syarat dan Tata Cara Pemberian Bantuan Hukum dan cum-cuma. Bantuan hukum bukan Penyaluran Dana Bantuan Hukum dilakukan dengan memberikan jasa dengan tarif tertentu oleh pemberi bantuan hukum tetapi dilakukan secara gratis. Mengenai pemberi bantuan hukum, tidak dijelaskan siapa yang memberi bantuan hukum, apakah advokat, dosen, paralegal dan Pasal 13 ayat (2) dan ayat (3) mengenai kebolehan dosen terlibat bersama avokat memberi bantuan hukum apabila pemberi bantuan hukum tidak memiliki jumlah advokat yang memadai dikarenakan jumlah penerima mahasiswa. Undang-undang bantuan hukum hanya menjelaskan bahwa bantuan hukum dalam jumlah banyak. Kemudian Pasal 16 ayat (1) PP tersebut pemberi bantuan hukum adalah menyatakan bahwa pemberian bantuan hukum secara non litigasi dapat 
dilakukan oleh advokat, paralegal, dosen, dan mahasiswa fakultas hukum dalam lingkup pemberi bantuan hukum yang telah lulus verifikasi dan akreditasi.

\section{Peran LKBH-FH UNCEN dalam Tri Dharma Perguruan Tinggi}

\section{Dharma Pendidikan}

Didalam kurikulum FH Uncen bagi mahasiswa semester VII ada mata kuliah praktek peradilan, dan mata kuliah kekhususan wajib dan mata kuliah kekhususan pilihan. Mata kuliah Praktek Peradilan, terdiri dari Praktek Peradilan Pidana, Praktek Peradilan Perdata dan Praktek peradilan Tata Usaha Negara (TUN), yang pelaksanaannya menjadi tanggung jawab LKBH. Adapun tenaga dosen yang menjadi pembimbing diambil dari dosen bagian Hukum Acara, Hukum Pidana, Hukum Perdata dan Hukum Administrasi/Hukum Tatanegara.

Praktek Peradilan Pidana, mahasiswa dikelompokkan, kemudian menyiapkan kasus/putusan perkara pidana, membagi peran dalam kelompok pidana yaitu majelis hakim, panitera, jaksa penuntut umum, polisi, juru sumpah, terdakwa, penasehat hukum, saksi-saksi. Pembuatan skenario latihan/praktek sesuai tahapan persidanngan dan kelengkapan surat atau jawabannya mulai dari surat kuasa khusus penasehat hukum, eksepsi, saksi-saksi, pemeriksaan terdakwa, surat tuntutan jaksa penuntut umum, pembelaan, replik, duplik dan putusan hakim.

Praktek Peradilan Perdata, mahasiswa dikelompokkan, kemudian menyiapkan kasus/putusan perkara perdata, membagi peran dalam kelompok perdata yaitu majellis hakim dan panitera, penggugat dan kuasa hukumnya, tergugat dan kuasanya, juru sumpah, saksi-saksi penggugat dan saksi-saksi tergugat. Pembuatan skenario latihan/praktek sesuai tahapan persidangan dan kelengkapan surat atau jawaban mulai: surat kuasa khusus para pihak, upaya damai, jawaban tergugat, replik duplik, bukti surat dan saksi dari penggugat, bukti surat dan saksi dari tergugat, kesimpulan dan putusan hakim.

Praktek Peradilan TUN, mahasiswa dikelompokkan, kemudian menyiapkan menyiapkan kasus/putusan perkara TUN, membagi peran dalam kelompok TUN yaitu: majelis hakim, panitera pengganti, petugas ruang 
sidang, penggugat dan kuasa pengabdian kepada masyarakat. hukumnya, tergugat dan kuasa Pengabdian kepada Masyarakat adalah hukumnya, juru sumpah, saksi-saksi kegiatan sivitas akademika yang penggugat dan saksi-saksi tergugat. memanfaatkan Ilmu Pengetahuan dan Pembuatan skenario latihan/praktek Teknologi untuk memajukan sesuai tahapan persidangan dan kesejahteraan masyarakat dan kelengkapan surat atau jawaban mulai mencerdaskan kehidupan bangsa. dari surat kuasa khusus para pihak, Dalam konteks inilah, kehadiran pemeriksaan persiapan, pembacaan LKBH perguruan tinggi merupakan gugatan dan jawaban tergugat, replik dan duplik, bukti surat dan saksi dari penggugat, bukti surat dan saksi dari tergugat, kesimpulan dan putusan hakim.

Data yang diperoleh dari Sekretaris bagian Hukum Acara, Tahun 2014 s/d 2016 Mahasiswa yang mengikuti praktek peradilan:

\section{Tabel 1}

Jumlah Mahasiswa yang mengikuti Praktek Peradilan dari Tahun 2014 s/d 2016

\begin{tabular}{c|c|c|c}
\hline NO. & T A H U N & KELAS & JUMLAH \\
\hline 1 & 2014 & Reguler & 110 \\
& & Non Reguler & 95 \\
\hline 2 & 2015 & Reguler & 256 \\
& & Non Reguler & 125 \\
\hline 3 & 2016 & Reguler & 161 \\
& & Non Reguler & 49 \\
\hline
\end{tabular}

\section{Dharma Pengadian Kepada Masyarakat}

Dalam Undang-Undang Nomor 12 Tahun 2012 tentang Pendidian Tinggi Pasal 1 angka 9 dinyatakan bahwa salah satu unsur dari tri darma perguruan tinggi adalah melaksanakan

wujud nyata dari darma perguruan tinggi dalam mengabdikan ilmu yang dimiliki untuk kepentingan masyarakat.

LKBH FH UNCEN dalam melaksanakan kegiatan bantuan hukum dapat mengambil peran untuk memberikan jasa bantuan hukum dalam bentuk kegiatan litigasi dan non litigasi. Kegiatan litigasi dapat dilakukan dengan memberikan layanan pendampingan dan/atau menjalankan kuasa yang dimulai dari tingkat penyidikan, dan penuntutan, pendampingan dan/atau menjalankan kuasa dalam proses pemeriksaan di persidangan atau pendampingan dan/atau menjalankan kuasa terhadap Penerima Bantuan Hukum di Pengadilan Tata Usaha Negara.

Selain kegiatan litigasi, LKBH perguruan tinggi dapat melakukan kegiatan non litigasi berupa 
penyuluhan hukum, konsultasi hukum, investigasi perkara baik secara elektronik maupun nonelektronik, penelitian hukum, mediasi, negosiasi, pemberdayaan masyarakat, pendampingan di luar pengadilan dan drafting dokumen hukum. Peran LKBH perguruan tinggi secara rinci berdasarkan pengalaman dapat dibagi menjadi beberapa kegiatan, yaitu:

1. Bidang Layanan Hukum

a. Membantu dan mendampingi para pihak dan potensial pihak berperkara khususnya dari golongan masyarakat miskin/tidak mampu untuk memperoleh informasi hukum, layanan hukum dan konsultasi hukum secara cuma-cuma;

b. Memberikan layanan hukum berupa bantuan berperkara di pengadilan agama, menyusun surat gugatan, permohonan, jawaban dan eksepsi bagi para pihak yang berperkara; c. Memberikan layanan informasi hukum berupa kegiatan pengayaaan wawasan kesadaran hukum kepada para pihak, potensial para pihak yang datang ke biro;

d. Memberikan layanan informasi hukum melalui layanan telepon untuk memperoleh bantuan hukum dan konsultasi hukum pada jam kerja dengan para konsultan;

e. Memberikan layanan bimbingan kepada masyarakat yang datang ke LKBH mengenai pentingnya masyarakat memilki identitas hukum (akta nikah dan cerai);

2. Bidang Konsultasi Hukum

a. Memberikan konsultasi kepada para pihak dan potensial pihak berperkara khususnya dari golongan masyarakat miskin/tidak mampu untuk memperoleh informasi hukum dari para konsultan hukum secara cumacuma; 
b. Memberikan konsultasi denda limapuluh juta rupiah. hukum dalam lingkup Namun sejak dilakukan judicial kewenangan absolut. review terhadap Undang-Undang

\section{Dharma Penelitian}

Dari data penanganan kasus, baik yang litigasi maupun yang non litigasi, kemudian ditindak lanjuti dengan penelitian, bisa dilakukan joint research policy dengan lembaga terkait seperti Kanwil Hukum dan HAM Propinsi Papua (sudah ada kerjasama dengan Fakultas Hukum), maupun sumber dana yang lain, dalam rangka melakukan evaluasi dan menemukan solusi penyelenggaraan peradilan yang bersih.

\section{PENUTUP}

Sejak Undang-Undang Nomor 18 Tahun 2003 tentang Advokat diberlakukan, posisi Laboratorium Klinik dan Bantuan Hukum sebagai organisasi yang memberikan jasa bantuan hukum secara cuma-cuma nyaris hilang karena di dalam Pasal 31 terdapat larangan dan sanksi pemidanaan bagi orang yang menjalankan bantuan hukum atau jasa hukum dan bertindak seolah-olah Advokat dengan ancaman pidana penjara maksimal 5 (lima) tahun dan Advokat Pasal 31 tersebut, kedudukan LKBH perguruan tinggi semakin jelas yaitu diperbolehkan memberikan bantuan hukum dengan ketentuan yang lebih selektif sebagaimana diatur dalam Undang-Undang Nomor 16 Tahun 2011 tentang Bantuan Hukum dan Peraturan Pemerintah Nomor 42 Tahun 2013.

Kedudukan yang jelas seperti itu berimplikasi pada peran yang bisa dilakukan oleh perguruan tingggi melalui LKBH yang dimilikinya, yaitu melakukan litigasi dan non litigasi kepada masyarakat yang sedang memiliki kasus hukum. Dengan keterlibatan perguruan tinggi memberikan bantuan hukum, maka perguruan tinggi telah mengabdikan ilmunya bagi kepentingan masyarakat.

\section{DAFTAR PUSTAKA}

Abdurrahman dan Ridwan Sahrani, (1987). Hukum dan Peradilan, Bandung: Alumni.

BPHN, (2013). Panduan veri kasi/Akreditasi Organisasi Bantuan Hukum, Jakarta: BPHN. 
COLPI and Open Society Institute, (2001). Manual on Street LawType Teaching Clinics at Law Schools, Hungary.

David F. chavkin, (2002). Clinical Legal Education Textbook for Law School Clinical Programs, Ohio: Anderson Publishing Co., Cincinnati.

Frank S Bloch (Ed.), (2011). The Global Clinical Movement; Educating Lawyers for Social Justice, New York: Oxford University Press.

KIH, (2009). Kumpulan Karangan: Pembaharuan Pendidikan Tinggi Hukum di Indonesia Dalam Menghadapi Abad ke 21, 1995. Michael Allison dan Jude Kaye, Perencanaan Strategis Bagi Organisasi Nirlaba, Jakarta: Yayasan OBOR dan TIFA, 2005. Open Society Justice Initiative (OSJI), Pendidikan Hukum Klinik (terjemahan), Jakarta: ILRC.

Prof. R. Subekti, (1992). Bunga Rampai Ilmu Hukum, Bandung: Penerbit Alumni.

Roy Stucky et al., (2007). Best Practies for Legal Edication, USA: Clinical Legal Education Assosiation.

Sidarta (Ed), (2012). Mochtar Kusumaatmaja dan Teori Hukum Pembangunan: Eksistensi dan Implikasi, Jakarta: Epistema Institute dan HuMa.

Uli Parulian Sihimbing, dkk, (2008). Mengelola Legal Klinik, ILRC, Jakarta: ILRC.
Uli Parulian, dkk, (2008). Kertas Kerja Revitalisasi Lembaga Konsultasi dan Bantuan Hukum dalam Rangka Memperkuat Akses Keadilan bagi Masyarakat Marginal, Jakarta: KHN dan ILRC.

Dr. Artidjo Alkostar, Pembaharuan Pendidikan Hukum dalam Konteks Penegakan Hukum. Makalah disampaikan dalam seminar sehari Menggagas Pembaruan Pendidikan Hukum di Indonesia, diselenggarakan oleh ILRC, Jakarta, 16 Desember 2009.

Marina Berbec-Rostas, "Introduction to Training and CLE General Overview." Paper presented at the First Southeast Asian Clinical Legal Education Teachers' Training, held by Open Society Justice Initiave dan Human Rights Center Ateneo Law School, Manila, the Philipines, January 30-Febuary 3, 2007.

Anthon F. Susanto, (2014). Pendidikan Hukum Klinik di FH Universitas Pasundan Bandung: Mitra Hukum, ILRC, Edisi 4 Nopember-Desember 2009.

Putusan Nomor 006/PUU-II/2004 mengenai Pengujian UndangUndang Advokat UndangUndang No. 16 Tahun 2011 tentang Bantuan Hukum

Peraturan Pemerintah No. 42 Tahun 2013 tentang Syarat dan Tata Cara Pemberian Bantuan Hukum dan Penyaluran Dana Bantuan Hukum. 